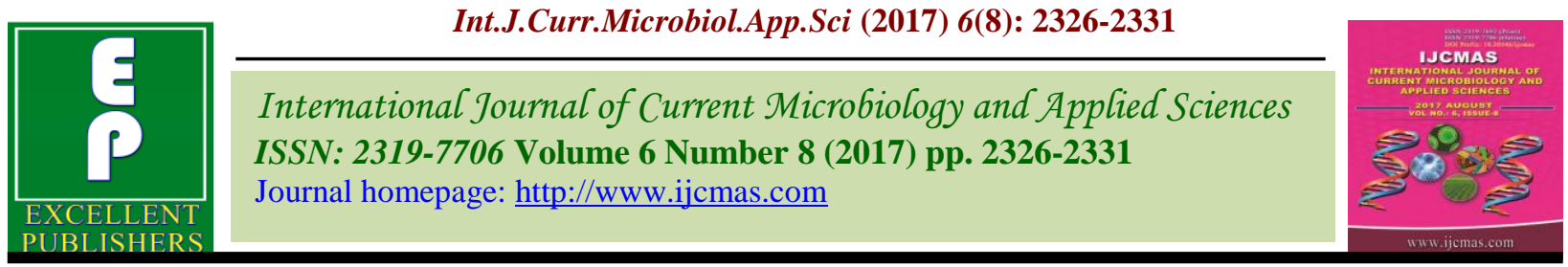

Original Research Article https://doi.org/10.20546/ijcmas.2017.608.274

\title{
Socio- Economic Features of the Respondent Households of MGNREGA in North-Eastern Karnataka, India
}

\author{
P. Divakar Reddy and Salla Sowjanya*
}

Department of Agricultural Economics, College of Agriculture, PJTSAU, Hyderabad, India

*Corresponding author

\section{A B S T R A C T}

Keywords

Socio-Economic

feature, North-

Eastern

Karnataka.

Article Info

Accepted:

21 June 2017

Available Online:

10 August 2017
The present study was undertaken in Kalaburagi district of Karnataka state during the agricultural year 2013-14. A multistage random sampling procedure was adopted for the selection of sample respondents. Two villages from each taluka of fully and partially implemented villages and from each village 30 participants were selected randomly. Thus, totally 120 sample respondents (60 from fully and 60 from partially implemented MGNREGA villages) were selected. The share of women in number of registered MGNREGA workers was more than half of the members in fully and partially implemented MGNREGA villages respectively. With regard to social category SC households were 13.23and 11.53 per cent, ST households were 4.34 and 3.84 per cent and households belonging to other categories were 82.43 per cent and 84.16 per cent in fully and partially implemented MGNREGA villages respectively

\section{Introduction}

MGNREGA is the World's largest employment guarantee Act implemented by Government of India by mobilizing greater budget resources, it becomes extremely pertinent to look at the effectiveness of the Act in providing both short and long-term food security through work on improvement of agriculture. There have been a few studies examining the impact of MGNREGA on employment generation, additional income generated by the casual labour, migration, women empowerment and developmental potential. Still, the potential of MGNREGA in reaching the poor is unsurpassed as it is now being implemented in all the districts in India.
Though MGNREGA was implemented during 2006, there were no concrete studies taken up to examine its economic impact on benefits, income, savings pattern and extent of employment after the implementation of the scheme. Hence, in view of the paramount importance of the scheme for improving the livelihood of rural poor through public investment.

Evolving the design of the wage employment programmes to more effectively fight poverty, the Central Government formulated the National Rural Employment Guarantee Act (MGNREGA) in 2005. With its legal 
framework and rights-based approach, MGNREGA provides employment to those who demand it and is a paradigm shift from earlier programmes. Notified on September 7, 2005, MGNREGA aims at enhancing livelihood security by providing at least one hundred days of guaranteed wage employment in a financial year to every rural household whose adult members volunteer to do unskilled manual work. The Act covered 200 districts in its first phase, implemented on February 2, 2006, and was extended to 130 additional districts in 2007- 2008. All the remaining rural areas have been notified with effect from April 1, 2008. The works undertaken through MGNREGA give priority to activities related to water harvesting, groundwater recharge, drought-proofing, and flood protection. Its focus on eco-restoration and sustainable livelihoods will lead over time, to an increase in land productivity and aid the workers in moving from wage employment to sustainable employment. Almost $80 \%$ works relate to soil and water conservation. MGNREGA works by their very nature place stress on increasing land productivity, recharging ground water and increasing water availability.

Arulprakash (2004) reported that majority of the SGSY respondents in Thiruvallur district of Tamil Nadu (56.66 \%) were middle aged while 28.34 per cent were young and remaining $(15 \%)$ were old aged and also found that nearly 40 per cent of the beneficiaries had primary education followed by 21.66 per cent had middle school level of education, 14.17 per cent and 6.67 per cent of the beneficiaries had high school, PUC and above level of education respectively, and 20 per cent of the beneficiaries were illiterate. This study also reported that nearly three forth of the beneficiaries were landless and only one fourth of the beneficiaries were land owners. Among the land owners, 46.87 per cent were small farmers followed by marginal farmers $(34.37 \%)$ and semi-medium farmers $(18.75 \%)$. Three fourth of the beneficiaries of SGSY were grouped under BPL category and the rest were grouped in the above poverty line category. Karemullah et al., (2009) found that, among the employment beneficiaries $(n=60)$ in Andhra Pradesh, 62 per cent were farmers and 38 per cent were landless labourers. The average land holding size of such farmers was 1.65 hectare. And land development $(34 \%)$ followed by water conservation $(30 \%)$ were the two major interventions done under the MGNREGA in Andhra Pradesh. During the past 3 years, 22375 works were completed in the Ananthapur district contributing to natural resources development in farmers land. The total expenditure on this account was of ₹ 16455 lakh. The scheme provided employment to 5.66 lakh persons of 3.14 lakh households in the district during the period 2006-09.

Among different types of work completed under the scheme, water conservation accounted for the highest share (56\%) followed by land development (29\%), irrigation facilities (4\%), renovation of traditional water bodies (3\%), drought proofing and plantation (3\%), rural connectivity (3\%) and micro and minor irrigation works $(1 \%)$. Sudha Narayanan et al., (2014) found that, a majority of the works undertaken, around $75 \%$, explicitly supports agricultural activities, via land levelling, horticulture and water conservation and harvesting works on public lands. The remaining works include roads and afforestation, some of which implicitly support agriculture as well. In the context of critiques of the MGNREGA, it is apparent that Maharashtra's MGNREGA is supportive of agriculture. About $37 \%$ of beneficiaries in the former are from SC/ST/OBC to $73 \%$ for the latter. The beneficiaries for works such as roads and afforestation were more diverse as 
one would expect; they also have a larger reach in terms of the extent of benefits.

\section{Materials and Methods}

The present study was undertaken in Kalaburagi district of Karnataka state during the agricultural year 2013-14.

Kalaburagi district is one of the 30 districts of Karnataka state in southern India. Kalaburagi city is the administrative headquarters of the district. This district is situated in Northern Karnataka between $76^{\circ} 04^{\prime}$ and $77^{\circ} 42^{\prime}$ East longitude, and $17^{\circ} 12^{\prime}$ and $17^{\circ} 46^{\prime}$ North latitude, covering an area of $10,951 \mathrm{~km}^{2}$. This district is bounded on the west by Vijaypura district and Solapur district of Maharashtra State, on the north by Bidar district and Osmanabad district of Maharashtra State, on the south by Yadgir district, and on the east by Ranga Reddy district of Telangana state.

A multistage random sampling procedure was adopted for the selection of sample respondents. Two villages from each taluka of fully and partially implemented villages and from each village 30 participants were selected randomly. Thus, totally 120 sample respondents (60 from fully and 60 from partially implemented MGNREGA villages) were selected. For evaluating the specific objectives designed for the study, required primary data was collected from the particicpants for the agriculture year 2013-14.

\section{Results and Discussion}

Socio- economic features of the respondent households

Socio-economic characteristics of the participant households in fully and partially implemented MGNREGA villages

Socio-economic characteristics of the respondent households in the sample villages presented in table 1, the average number of family members per household was found to be five in case of MGNREGA participants in fully implemented villages and in case of partially implemented villages' average number of family members per household was four. The average age of the respondent, was 42 years in fully implemented villages and 43 years in case of partially implemented MGNREGA villages. It is evident from table 1, that 30.00 and 33.34 per cent of MGNREGA participants were having their main occupation as agriculture in fully and partially implemented MGNREGA villages, and those who work as agricultural labour constitute 45.00 and 20.00 per cent and those pursuing other types of works were only 25.00 and 46.67 per cent in fully and partially implemented MGNREGA villages, respectively.

Educational status of the sample respondents revealed that, 30.00 per cent households were illiterate, 25.00 per cent people had primary school, 23.33 per cent people were completed their high school education and 21.67 per cent people had PUC and above education in fully implemented MGNREGA villages. Whereas in case of partially implemented MGNREGA villages 28.33 per cent had primary education, 21.66 per cent had primary, 26.67 per cent had high school education and only 23.33 per cent of them had PUC and above qualification respectively. Average size of landholdings was owned by the participants 1.15 acres in fully implemented MGNREGA villages and 1.35 acres in partially implemented MGNREGA villages (Table 1).

Coverage of households in fully and partially implemented MGNREGA villages

The number of registered MGNREGA workers during 2013-14 and their category wise classification in the sample villages were provided in table 2. The share of women in number of registered MGNREGA workers 
was 53.24 and 54.23 per cent, in fully and partially implemented MGNREGA villages respectively. With regard to social category Scheduled caste households covered were 13.23 and 11.53 per cent, Scheduled tribes households were 4.34 and 3.84 per cent, households belonging to other categories were 82.43 per cent and 84.16 per cent in fully and partially implemented MGNREGA villages respectively.

The average number of participant households whose main occupation was agriculture labour in case of fully implemented MGNREGA villages $(33.33 \%)$ compared to partially implemented MGNREGA villages where in agriculture was the main occupation among 33.33 per cent of the households. In case of agricultural labour in fully implemented MGNREGA villages (45.00\%) and partially implemented MGNREGA villages $(20.00 \%)$. Whereas, in case of others in participant households $(25.00 \%)$ in fully implemented MGNREGA villages, in case of partially implemented MGNREGA villages was $(46.66 \%)$.

Moderate phenotypic and genotypic coefficients of variation (10-19\%) were observed for number of branches per plant, days to first flowering and days to $50 \%$ flowering. The parameters like number of flower clusters per plant and number of flowers per cluster exhibited moderate coefficient of variation at genotypic level.

There is the opportunity for improving these characters in the desirable direction through selection. This agrees with findings of Ramesh Kumar and Arumugam (2013), Lokesh et al., (2013), Gavade and Ghadage (2015). Low estimates of phenotypic and genotypic coefficient of variation were observed for plant height, days to first fruit harvest and days to last fruit harvest. Similar results were reported by Kumar et al., (2012), Gavade and Ghadage (2015).

Table.1 Socio-economic characteristics of the respondents in the sample villages

\begin{tabular}{|c|c|c|c|c|}
\hline $\begin{array}{l}\text { Sl. } \\
\text { No. }\end{array}$ & Particulars & Unit & $\begin{array}{c}\text { Fully } \\
\text { implemented }\end{array}$ & $\begin{array}{c}\text { Partially } \\
\text { Implemented }\end{array}$ \\
\hline $\mathbf{I}$ & Family details & & & \\
\hline 1 & Family size & No. & 5 & 4 \\
\hline 2 & $\begin{array}{l}\text { Average age of the } \\
\text { respondent }\end{array}$ & Year & 42 & 43 \\
\hline II & Education & & & \\
\hline 1 & Illiterate & No. & $18(30.00)$ & $17(28.33)$ \\
\hline 2 & Primary & No. & $15(25.00)$ & $13(21.66)$ \\
\hline 3 & High school & No. & $14(23.33)$ & $16(26.67)$ \\
\hline 4 & PUC and above & No. & $13(21.67)$ & $14(23.33)$ \\
\hline III & Occupation & & & \\
\hline 1 & Agriculture & No. & $18(30.00)$ & $20(33.33)$ \\
\hline 2. & Agricultural labour & No. & $27(45.00)$ & $12(20.00)$ \\
\hline 3 & Others & No. & $15(25.00)$ & $28(46.67)$ \\
\hline IV & $\begin{array}{l}\text { *Average size of } \\
\text { landholding }\end{array}$ & & & \\
\hline 1 & Rainfed & Acre & 1.2 & 1.4 \\
\hline 2 & Irrigated & Acre & 1.1 & 1.3 \\
\hline
\end{tabular}


Table.2 Coverage of households in MGNREGA implemented villages

\begin{tabular}{|c|c|c|c|}
\hline $\begin{array}{l}\text { Sl. } \\
\text { No. }\end{array}$ & Particulars & $\begin{array}{l}\text { Fully implemented } \\
(n=60)\end{array}$ & $\begin{array}{c}\text { Partially } \\
\text { implemented }(n=60)\end{array}$ \\
\hline 1 & No. of households & 4440 & 1058 \\
\hline 2 & Total population & 13320 & 10380 \\
\hline 3 & $\begin{array}{l}\text { No.of registered households } \\
\text { under MGNREGA }\end{array}$ & $2180(16.36)$ & $458(4.4)$ \\
\hline 4 & Registered workers & $4598(34.51)$ & $1300(12.52)$ \\
\hline 5 & \multicolumn{3}{|c|}{ Social category covered under MGNREGA } \\
\hline & $\mathrm{SC}$ & $608(13.23)$ & $150(11.53)$ \\
\hline & ST & $200(4.34)$ & $50(3.84)$ \\
\hline & Others & $3790(82.43)$ & $1100(84.16)$ \\
\hline & \multicolumn{3}{|c|}{ (Coverage under MGNREGA according to gender) } \\
\hline & Male & $2150(46.00)$ & $595(48.76)$ \\
\hline & Female & $2448(54.00)$ & $705(53.23)$ \\
\hline
\end{tabular}

The average number of participant households who were illiterate preferred to work in MGNREGA $(30.00 \%)$ than in any other works in case of fully implemented MGNREGA villages, as they had much less opportunity elsewhere and work was available on demand under MGNREGA. The persons with PUC and above qualification, who do not prefer manual work, were more $(23.34 \%)$ in the partially implemented MGNREGA villages. The average number of family members per household was greater in case of fully MGNREGA participant households compared to partially implemented MGNREGA villages. The probable reason may be that, if the family size is large, additional members will be available to participate in the scheme. Higher age of head of the household (43 years) was seen in case of participant households in partially implemented MGNREGA villages than fully implemented villages (42 years). Since the MGNREGA works were non regular type like water conservation, road construction that involved higher degree of hard work, households with younger family heads preferred to work under the scheme. There was not much difference seen in the average size of landholding owned by the participant households (1.15, 1.35 acres) in fully and partially implemented MGNREGA villages respectively. Some difference was having lesser area and majority of them used their lands for cultivating food crops for family consumption. Similar pattern of findings was reported by Sudha (2008).

Coverage of households and persons in fully and partially implemented MGNREGA villages

Out of total number of registered workers in MGNREGA in the sample villages, more than half of them were women in fully and partially implemented MGNREGA villages respectively. This is in agreement with the findings of Jayati and Ghosh (2009) who found that, the share of women participation in MGNREGA works is around 49 per cent and well above the norms of MGNREGA. Share of population from census of India 2001 indicated that 16.2 per cent of the total population and 8.1 per cent of the total population belong to SC and ST categories respectively. Whereas the percentage of SC households in the total number of registered MGNREGA households in the sample villages were 10.38 per cent less than the SC 
and ST population household respondents 4.76 per cent. This is in contrast with the results obtained by Jayati and Ghosh (2009) which shows that participation of SC households is almost double of its proportion in the national population and that of SC households is nearly three times of its proportion in the country's population. The overall figures showed that, there was no gender discrimination under MGNREGA and households belonging to all categories were given the opportunity to participate in the scheme.

In conclusion, the share of women in number of registered MGNREGA workers was more than half of the members in fully and partially implemented MGNREGA villages respectively. With regard to social category SC households were 13.23 and 11.53 per cent, ST households were 4.34and 3.84 per cent and households belonging to other categories were 82.43 per cent and 84.16 per cent in fully and partially implemented MGNREGA villages respectively. The average number of family members per household was found to be five in case of MGNREGA participants in fully implemented villages and in case of partially implemented villages was four respectively. The average age of the respondent was more or less same in fully and partially implemented MGNREGA villages (42 years). Around 30.00 and 33.34 per cent of MGNREGA participants were having their main occupation as agriculture in fully and partially implemented MGNREGA villages and those who work as agricultural labour constituted 45.00 and 20.00 per cent and those pursuing other types of works were only 25.00 and 46.67 per cent in fully and partially implemented MGNREGA villages.

\section{References}

Arulprakash, R., 2004, Analysis of Swarnajayanti Gram Swarozgar Yojana in Salem and Thiruvallur districts of Tamil Nadu, M.Sc.(Agri.) Thesis (unpublished), Univ. Agric. Sci., Dharwad, Karnataka (India).

Jayati and Ghosh, 2009, Equity and inclusion through public expenditure: The potential of the NREGS. International Conference on NREGA, 21- 22 January, 2009. Ministry of Rural Development, Government of India and ICAR, New Delhi.

Karemullah, K., Reddy, K.S., Rao, C. A. R., Kumar, S. and Venkateswarlu, B., 2009, Soil and water conservation works through NREGA in Andhra PradeshAn analysis of livelihood impact. Agric. Econ. Res. Rev., 22 (4): 443-450.

Sudha, N., 2008, Employment guarantee, women's work and child care. Economic and Political Weekly, 43(9): 10-13.

Sudha Narayanan, Krushna Ranaware, Upasak Das and Ashwini Kulkarni., 2014, MGNREGA works and their impacts. A Rapid Assessment in Maharashtra IGIDR, Mumbai.

\section{How to cite this article:}

Divakar Reddy, P. and Salla Sowjanya. 2017. Socio- Economic Features of the Respondent Households of MGNREGA in North-Eastern Karnataka. Int.J.Curr.Microbiol.App.Sci. 6(8): 2326-2331. doi: https://doi.org/10.20546/ijcmas.2017.608.274 